\title{
A pentaplex PCR assay for the rapid detection of methicillin-resistant Staphylococcus aureus and Panton-Valentine Leucocidin
}

\author{
Hassanain Al-Talib*1, Chan Yean Yean ${ }^{1}$, Alyaa Al-Khateeb ${ }^{2}$, Habsah Hassan ${ }^{1}$, \\ Kirnpal-Kaur Banga Singh ${ }^{1}$, Karim Al-Jashamy ${ }^{3}$ and \\ Manickam Ravichandran ${ }^{4}$
}

Address: ${ }^{1}$ Department of Medical Microbiology and Parasitology, School of Medical Sciences, Universiti Sains Malaysia Kota Bharu, Malaysia, ${ }^{2}$ Human Genome Center, School of Medical Sciences, Universiti Sains Malaysia, Kota Bharu, Malaysia, ${ }^{3}$ Faculty of Health \& Life Sciences, Management \& Science University, Shah Alam, Malaysia and ${ }^{4}$ Faculty of Applied Sciences, AIMST University, Kedah, Malaysia

Email: Hassanain Al-Talib* - hassanainiy@yahoo.com; Chan Yean Yean - yeancyn@yahoo.com; Alyaa Al-Khateeb - alyaa_1974@yahoo.com; Habsah Hassan - habsah@kb.usm.my; Kirnpal-Kaur Banga Singh - kiren@kck.usm.my; Karim Al-Jashamy - aljashamy@yahoo.com; Manickam Ravichandran - mravichandran08@gmail.com

* Corresponding author

Published: 28 May 2009

BMC Microbiology 2009, 9:1 I3 doi:10.1 I86/I47I-2180-9-II3

This article is available from: http://www.biomedcentral.com/147I-2180/9/1 I3

(c) 2009 Al-Talib et al; licensee BioMed Central Ltd.

This is an Open Access article distributed under the terms of the Creative Commons Attribution License (http://creativecommons.org/licenses/by/2.0), which permits unrestricted use, distribution, and reproduction in any medium, provided the original work is properly cited.
Received: 2 January 2009

Accepted: 28 May 2009

\begin{abstract}
Background: Staphylococcus aureus is a major human pathogen, especially methicillin-resistant $S$. aureus (MRSA), which causes a wide range of hospital and community-acquired infections worldwide. Conventional testing for detection of MRSA takes 2-5 days to yield complete information of the organism and its antibiotic sensitivity pattern.

Results: The present study focused on the development of a pentaplex PCR assay for the rapid detection of MRSA. The assay simultaneously detected five genes, namely I6S rRNA of the Staphylococcus genus, femA of $S$. aureus, mecA that encodes methicillin resistance, lukS that encodes production of Panton-Valentine leukocidin (PVL), a necrotizing cytotoxin, and one internal control. Specific primer pairs were successfully designed and simultaneously amplified the targeted genes. The analytical sensitivity and specificity of the pentaplex PCR assay was evaluated by comparing it with the conventional method. The analytical sensitivity of the pentaplex PCR at the DNA level was found to be $10 \mathrm{ng}$ DNA. The analytical specificity was evaluated with 34 reference staphylococci and non-staphylococcal strains and was found to be $100 \%$. The diagnostic evaluation of MRSA carried out using 230 clinical isolates, showed $97.6 \%$ of sensitivity, $99.3 \%$ of specificity, $98.8 \%$ of positive predictive value and $98.6 \%$ of negative predictive value compared to the conventional method. The presence of an internal control in the pentaplex PCR assay is important to exclude false-negative cases.

Conclusion: The pentaplex PCR assay developed was rapid and gave results within $4 \mathrm{~h}$, which is essential for the identification of Staphylococcus spp., virulence and their resistance to methicillin. Our PCR assay may be used as an effective surveillance tool to survey the prevalence of MRSA and PVL-producing strains in hospitals and the community.
\end{abstract}




\section{Background}

Staphylococcus aureus is a facultative pathogenic Gram-positive bacterium that is well known as colonizer of the human skin, and is a leading cause of diseases ranging from mild skin and soft tissue infections to life-threatening illnesses, such as deep post-surgical infections, septicemia and toxic shock syndrome [1]. Methicillin-resistant $S$. aureus (MRSA) and methicillin-sensitive $S$. aureus (MSSA) are responsible for a large proportion of nosocomial infections, which makes treatment difficult [2]. During the past decade, an increasing number of MRSA cases has been encountered globally among healthy community residents [3]. These isolates are referred to as community-acquired MRSA (CA-MRSA), which are genetically and phenotypically different from representative hospitalacquired MRSA (HA-MRSA), in relation to their antibiotic resistance patterns, and by the allocation of their staphylococcal chromosomal cassette (SCCmec) types, IV and V $[3,4]$. Coagulase-negative staphylococci (CoNS) were regarded as harmless skin commensals prior to the 1970s; however, they are now recognized as important causes of human infections $[5,6]$. CoNS are also among the most commonly isolated bacteria in clinical microbiology laboratories [7]. Furthermore, CoNS often serve as reservoirs of antimicrobial-resistance determinants, since they usually have a high prevalence of multidrug resistance. Therefore, it is important to describe and distinguish $S$. aureus strains and CoNS [8]. Methicillin resistance in staphylococci is mainly mediated by the over-production of PBP2a, an additional modified penicillin-binding protein with low affinity for $\beta$-lactam antibiotics. The mecA gene, the structural determinant that encodes PBP2a, is therefore considered as a useful molecular marker of putative methicillin resistance in $S$. aureus and CoNS $[9,10]$.

Clinical laboratory tests for methicillin resistance are highly dependent on growing conditions such as temperature, $\mathrm{pH}$ and salt concentration [11]. Thus, these factors emphasize the need to develop a rapid, accurate and sensitive method for detection of methicillin-resistant staphylococci, which does not depend on growth conditions. Nucleic-acid-based tests using PCR are increasingly being used in laboratories to replace timeconsuming, labor intensive and less sensitive conventional diagnostic methods, such as biochemical identification and Kirby-Bauer antimicrobial susceptibility tests. Various PCR methods have been developed to identify: (i) Staphylococcus genus [12]; (ii) methicillin-resistance [13]; and (iii) Panton-Valentine leukocidin (PVL)-producing Staphylococcus genus [14]. These methods do not detect all of the above-mentioned targets simultaneously. Hence, the present study focused on the design of a pentaplex PCR for methicillin-resistant staphylococci with an internal control for the detection of Staphylococcus genus (16S
rRNA gene), methicillin-resistant staphylococci (mecA gene), community-acquired MRSA (lukS gene), and discrimination between $S$. aureus and CoNS (femA gene).

\section{Results}

In the present study, the pentaplex PCR was optimized successfully to identify the Staphylococcus genus (16S rRNA), $S$. aureus species (femA), methicillin resistance (mecA) and PVL toxin (lukS) genes simultaneously. Stepwise optimization of primer concentration, annealing temperature, $\mathrm{MgCl}_{2}$, dNTP and Taq polymerase was carried out. The pentaplex PCR gave the best results when $3.13 \mathrm{mM} \mathrm{MgCl}_{2}, 200 \mu \mathrm{M}$ dNTP, $0.75 \mathrm{U}$ Taq polymerase and $60^{\circ} \mathrm{C}$ annealing temperature were used. The analytical sensitivity of the pentaplex PCR at the DNA level was found to be 10 ng DNA (data not shown), whereas, at the bacterial level, it was found to be $10^{4} \mathrm{CFU} / \mathrm{mL}$ (data not shown). The analytical specificity of the pentaplex PCR assay at the genus level was determined using 10 staphylococcal reference strains and found to be positive for the Staphylococcus genus specific 16S rRNA gene. A representative gel picture of methicillin resistance with reference strains is shown in Figure 1, while the other 10 Gram-positive non-staphylococcal and 13 Gram-negative strains were negative. All the reference strains of $S$. aureus were positive for femA gene by pentaplex PCR, while other CoNS species were negative (Table 1 ). Hence, all methicillin-resistant reference strains were positive for mecA gene by pentaplex PCR. However, the methicillin-sensitive reference strains were negative for mecA gene by pentaplex PCR (Table 1). Overall, the analytical specificity of pentaplex PCR was $100 \%$ for the detection of MRSA reference strains.

Upon completion of the standardization of the methicillin-resistant pentaplex PCR assay with reference strains, the assay was validated with 230 clinical isolates. Among these, all had 16S rRNA, 82 contained mecA, 178 had femA and none had luks genes by pentaplex PCR. However, by the conventional E-test antimicrobial susceptibility method, 83 of the isolates were methicillin-resistant staphylococci (oxacillin MIC $\geq 8 \mu \mathrm{g} / \mathrm{mL}$ ). One of the $S$. aureus isolates that was positive for mecA gene by pentaplex PCR was found to be sensitive to oxacillin by the conventional MIC method. The diagnostic accuracy of a pentaplex PCR for 16S rRNA and femA genes was determined using 230 clinical isolates and found to have $100 \%$ sensitivity, specificity, and positive and negative predictive values. However, the pentaplex PCR for the mecA gene detection showed $97.6 \%$ of sensitivity, $99.3 \%$ of specificity, and $98.8 \%$ of positive and $98.6 \%$ of negative predictive values in detecting methicillin-resistant staphylococci. 


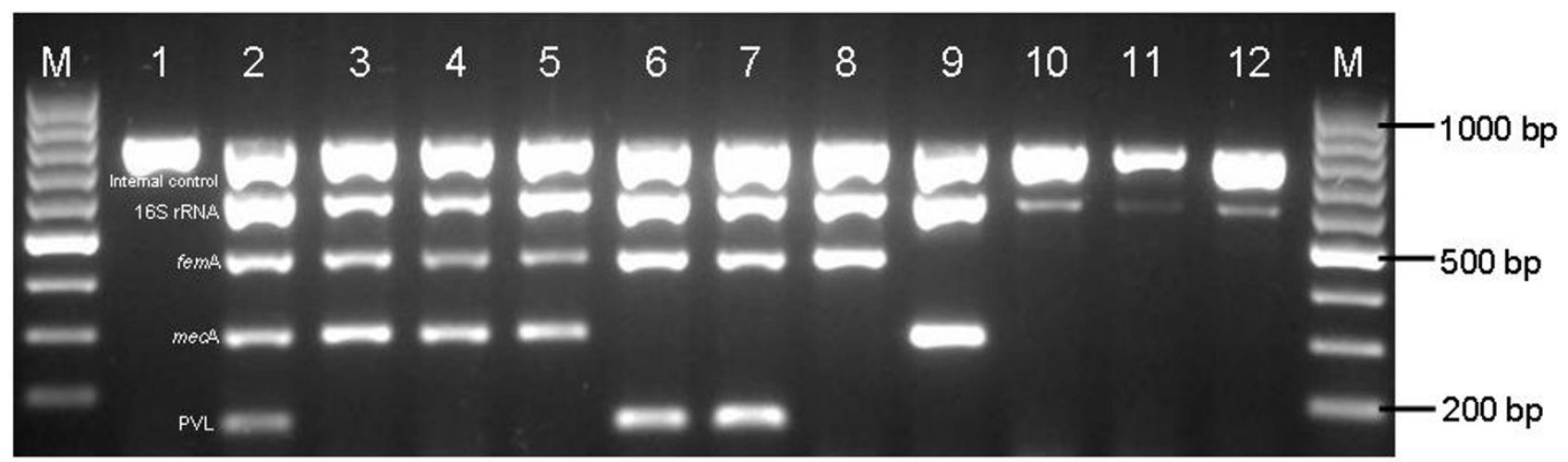

\section{Figure I}

Pentaplex PCR assay profile with reference strains. M, I00-bp marker; lane I, negative control; lane 2, Staphylococcal positive control; lane 3, ATCC 3359I (I6S rRNA, femA-S. aureus, mecA); lane 4, ATCC 33592 (I6S rRNA, femA-S. aureus, mecA); lane 5, ATCC 43300 (I6S rRNA, femA-S. aureus, mecA); lane 6, ATCC 25923 (I6S rRNA, femA-S. aureus, lukS); lane 7, ATCC 49775 (I6S rRNA, femA-S. aureus, lukS); lane 8, ATCC 5 I I 53 (I6S rRNA, femA-S. aureus); lane 9, CoNS methicillinresistant clinical isolate (I6S rRNA, mecA); lane I0, ATCC I4990 (I6S rRNA); lane II, ATCC 29970 (I6S rRNA); lane I2, ATCC I35I8 (I6S rRNA); M, I00-bp marker

\section{Discussion}

The present study is believed to be the first to develop a combined molecular test for the rapid identification and discrimination of the Staphylococcus genus from others, with simultaneous discrimination of methicillin-resistant from -susceptible staphylococcal strains, $S$. aureus from CoNS, and concomitant detection of PVL genes. Although there are numerous reports on PCR assays for the detection of methicillin resistance [15-17], only a few of them have incorporated internal controls in their assays to rule out false-negative results $[18,19]$. According to guidelines for Molecular Diagnostic Methods for Infectious Diseases [20], incorporation of an internal control in the reaction is essential for the diagnostic test to exclude false-negative results or the presence of inhibitors [21]. In the present study, the inclusion of a 759-bp internal control in the pentaplex PCR assay helped us to rule out false-negative results or PCR inhibitors. To deal with applicability and accuracy, we further applied our pentaplex PCR assay to test a total of 53 MRSA, 125 MSSA, 22 methicillin-sensitive CoNS, and 30 methicillin-resistant CoNS from routine clinical specimens obtained from Hospital Universiti Sains Malaysia.

The Staphylococcus genus consists of at least 35 unique species, and only a few have been recovered from humans [6]. Previously published staphylococcal genus specific primers $[22,23]$ do not target wholly conserved regions in the staphylococcal 16S rRNA gene, which results in misdetection of some important CoNS. Therefore, we designed a new conserved Staphylococcus genus-specific primer and included it in our new pentaplex PCR assay, which allowed us to detect most species and strains of staphylo- cocci (Table 1). The pentaplex PCR was found to be $100 \%$ sensitive and specific in detecting 16S rRNA genes among staphylococcal strains.

Another gene, femA, has been characterized as essential for the expression of methicillin resistance in $S$. aureus and is universally present only in $S$. aureus isolates. This gene has been implicated in cell wall metabolism and is present in large amounts in actively growing cultures [24]. Specific primers for femA were designed and used in the pentaplex PCR to survey various staphylococcal isolates from our culture collection. All 178 S. aureus cultures examined, regardless of the presence or absence of mecA, produced a positive result in PCR for femA. In contrast to the results with $S$. aureus, when 52 strains of CoNS were examined for the presence of the femA gene by pentaplex PCR, all were negative. The femA gene in the pentaplex PCR assay was able to rule out non-S. aureus staphylococci, as reported by Francois et al. [25].

The mecA gene is unique to methicillin-resistant staphylococci [26]. The DNA sequences of the mecA genes found in S. aureus and CoNS are $>99 \%$ identical [27]. Thus, the mecA gene represents a useful molecular component for rapid identification of MRSA and methicillin-resistant CoNS by PCR. One of the 147 MSSA isolates was shown to be mecA-positive by pentaplex PCR. Although genotypically the mecA gene was detected and confirmed by PCR, it is possible that the mecA gene is non-functional (nonPBP-2a producing) and is not expressed phenotypically or due to the presence of pseudogene [28]. Clinically, it is important to differentiate between classical type mecApositive MRSA strains among other borderline-resistant $S$. 
Table I: Bacterial species and strains used in this study and results of pentaplex PCR.

\begin{tabular}{|c|c|c|c|c|c|}
\hline No. Reference strains & I6S rRNAa & femA & mecA $^{b}$ & lukS & Internal control \\
\hline I. S. aureus (ATCC 3359I) & + & + & + & - & + \\
\hline 2. S. aureus (ATCC 33592) & + & + & + & - & + \\
\hline 3. S. aureus (ATCC 43300) & + & + & + & - & + \\
\hline 4. S. aureus (ATCC 25923) & + & + & - & + & + \\
\hline 5. S. aureus (ATCC 49775) & + & + & - & + & + \\
\hline 6. S. aureus (ATCC 51153$)^{\mathrm{e}}$ & + & + & - & - & + \\
\hline 7. S. epidermidis (ATCC I4990) & + & - & - & - & + \\
\hline 8. Staphylococcus haemolyticus (ATCC 29970) & + & - & - & - & + \\
\hline 9. Staphylococcus saprophyticus (ATCC I3518)d & + & - & - & - & + \\
\hline 10. CoNS methicillin-resistante & + & - & + & - & + \\
\hline II. Streptococcus spp. Group A (ATCC 196I5)e & - & - & - & - & + \\
\hline 12. Streptococcus spp. Group B (ATCC I240I)e & - & - & - & - & + \\
\hline 13. Streptococcus spp. Group Ge & - & - & - & - & + \\
\hline 14.Streptococcus spp. Group Fe & - & - & - & - & + \\
\hline 15. Bacillus subtilis (ATCC 6633)e & - & - & - & - & + \\
\hline 16.Listeria monocytogenes (ATCC 7644)e & - & - & - & - & + \\
\hline 17. Enterococcus faecium LMG $16192^{c}$ & - & - & - & - & + \\
\hline 18. Enterococcus faecalis (ATCC 292/2)e & - & - & - & - & + \\
\hline 19. Corynebacterium sppe & - & - & - & - & + \\
\hline 20. Escherichia coli (EHEC)e & - & - & - & - & + \\
\hline 2I. E. coli (EPEC) $\mathrm{e}$ & - & - & - & - & + \\
\hline 22.E. coli (ETEC) ${ }^{\mathrm{e}}$ & - & - & - & - & + \\
\hline 23. Klebsiella pneumoniae (ATCC I003I)e & - & - & - & - & + \\
\hline 24. Shigella sonnei (ATCC 2593I)e & - & - & - & - & + \\
\hline 25. Shigella flexneri (ATCC I2022)e & - & - & - & - & + \\
\hline 26. Shigella boydii (ATCC 9207)e & - & - & - & - & + \\
\hline 27.Proteus mirabilis (ATCC 29245) & - & - & - & - & + \\
\hline 28. Salmonella typhie & - & - & - & - & + \\
\hline 29. Pseudomonas aeruginosa (ATCC 27853)e & - & - & - & - & + \\
\hline 30.Yersinia enterocolitica (ATCC 237/5)e & - & - & - & - & + \\
\hline 31. Vibrio cholerae (OI classical)e & - & - & - & - & + \\
\hline 32. Citrobacter freundii (ATCC 8090$)^{\mathrm{e}}$ & - & - & - & - & + \\
\hline 33.Gardnerella sppe & - & - & - & - & + \\
\hline 34.Candida albicans (ATCC 1023I)e & - & - & - & - & + \\
\hline
\end{tabular}

a Staphylococcus genus

b methicillin-resistant genotype

c Reference strains from Belgian Co-ordinated Collections of Micro-organisms (BCCM), Ghent,

Belgium

d Obtained from Institute for Medical Research, Malaysia

e Department of Medical Microbiology and Parasitology, School of Medical Sciences, Universiti

Sains Malaysia.

aureus strains that result from hyperproduction of $\beta$-lactamases [11].

The mecA-positive isolates were either heterogeneous or homogeneous in their expression of resistance. When heterogeneous isolates are tested by standard conventional methods, some cells appear susceptible and others resistant, while almost all homogeneous isolates express resistance when tested by standard methods [29].

Production of PBP-2a may be stimulated during chemotherapy with $\beta$-lactam antibiotics, which converts heterogeneous isolates into oxacillin-resistant strains, therefore, the identification of methicillin-resistant staphylococci in the laboratory is complicated by the heterogeneous nature of the resistance, and by the variables that influence its expression (i.e., medium, inoculum size, $\mathrm{pH}$, temperature, and salt concentration) [30]. For these reasons, detection of $m e c \mathrm{~A}$ gene is crucial for precise discrimination of methicillin resistance among staphylococci.

Almost $100 \%$ of CA-MRSA strains contain the lukS gene, compared to $<5 \%$ of HA-MRSA. The PVL-encoding gene allows the production of a necrotizing cytotoxin, which may be responsible for staphylococcal invasiveness and virulence $[4,31]$. We included this gene in the pentaplex PCR assay to categorize our isolates and accurately discriminate CA-MRSA and HA-MRSA. 
None of the MRSA, MSSA and CoNS isolates harbor the PVL-encoding lukS gene. With regard to MRSA, this is not surprising because all MRSA isolates in our study were nosocomial organisms. A high prevalence of lukS gene among MSSA has been reported in the neighboring countries of Singapore and Indonesia, with none and low prevalence of lukS gene among MRSA [32,33]. The low prevalence in Malaysia is ascribed to restrictive antibiotic usage and a strict policy of national surveillance for MRSA.

Rapidly increasing prevalence of serious CA-MRSA infections and mortality have been reported globally [34-36], an accurate and rapid method of screening $S$. aureus isolates with lukS gene was a vital step for appropriate therapy and controlling the dissemination of this potentially virulent pathogen. In Malaysia, the presence of MRSA has been reported [37,38], and cases of MRSA infection and colonization have also been reported in the neighboring countries of Singapore and Indonesia [32,33].

The presented pentaplex PCR assay is robust and practicable for culture confirmation purposes. However, the $10^{4}$ $\mathrm{CFU} / \mathrm{mL}$ analytical sensitivity of this current pentaplex PCR assay might not sensitive enough for the direct testing of clinical specimens.

A previous study by Gosbell et al, in 2001 confirmed that MRSA-screen test gave excellent sensitivity and specificity for MRSA detection, and was quicker and cheaper than PCR [39], while other study showed lower sensitivity and specificity in detecting methicillin resistance in CoNS [40] and couldn't identify neither PVL toxin encoding gene among staphylococci nor differentiate between CA-MRSA and HA-MRSA. Hence the PCR assay developed in the present study will be useful in the epidemiological screening of MRSA patients or carriers. We are currently evaluating this assay for screening for MRSA carriage in Malaysia.

\section{Conclusion}

The PCR assay was able to detect four genes that are essential for the identification of $S$. aureus and its methicillinresistant genotypes simultaneously in a single test within $4 \mathrm{~h}$. The built-in internal control in this assay prevented false-negative results. The diagnostic accuracy was determined using 230 clinical specimens and showed $97.6 \%$ of sensitivity and $99.3 \%$ of specificity in detecting methicillin-resistant staphylococci. Hence, this test can be used as an effective diagnostic and surveillance tool to monitor the spread and emergence of MRSA.

\section{Methods \\ Study design}

This was a cross-sectional study in which the retrospective sample size was calculated by using PS software (Dupont
\& Plummer, 1997) using Dichotomous based on the sensitivity of the E-test and PCR at $100 \%$ and $98 \%$ respectively [41,42]. The Research and Ethics Committee, School of Medical Sciences, Universiti Sains Malaysia, approved the study protocol.

\section{Bacterial strains and clinical specimens}

The Staphylococcus spp. reference strains and other bacteria used in this study are listed in Table 1. A total of 230 retrospective Staphylococcus spp. that were isolated from routine clinical specimens obtained from Hospital Universiti Sains Malaysia, from March 2006 to February 2007, were used in this study. Among the 230 clinical isolates, 86 were from nasal samples, 45 from blood samples, 34 from pus samples, 19 each from body fluid, wounds and CSF samples, and eight from urine samples.

\section{Screening of Staphylococcus spp. from clinical specimens by the conventional method}

The clinical isolates were inoculated onto Columbia blood agar (Merck, NJ, USA) plates with 5\% sheep blood for $24 \mathrm{~h}$ at $37^{\circ} \mathrm{C}$. The staphylococcal isolates were identified morphologically and biochemically by standard laboratory procedures [43]. The coagulase plasma test (Remel, Lenexa, KS, USA) was performed on organisms that exhibited typical staphylococcal colony morphology, to allow for discrimination of $S$. aureus from CoNS. Susceptibility testing for methicillin resistance and other antibiotic resistance phenotypes was carried out by the KirbyBauer methods [44]. MIC of methicillin was determined by E-test kits (AB Biodisk, Solna, Sweden). The results were categorized according to CLSI standards. Reference strains used as controls were $S$. aureus (ATCC 33591), S. aureus (ATCC 25923), and S. epidermidis (ATCC 12228) (Table 1).

\section{Primer design for pentaplex PCR assay}

The 16S rRNA of Staphylococcus genus, and gene sequences for $f e m \mathrm{~A}, m e c \mathrm{~A}$ and lukS of $S$. aureus were obtained from GenBank [45], for DNA sequence alignment and primer design. The ClustalW program in Vector NTI version 9.0 software (Invitrogen, Carlsbad, CA, USA) was used to align the DNA sequences. The conserved and non-conserved regions of the DNA sequence alignments were visualized using GeneDoc software [46].

Based on the conserved regions of the alignment, specific primer pairs were designed to amplify the Staphylococcus genus. Specific primers of $S$. aureus species were designed based on the non-conserved regions of $f e m \mathrm{~A}$ gene sequences. Methicillin-resistance specific primers were designed based on the conserved regions of mecA DNA sequences. For the PVL-encoding gene, specific primers were designed based on lukS gene. The five primer pairs (Research Biolabs, KL, Malaysia) were designed in such a 
way that the PCR products ranged from 151 to $759 \mathrm{bp}$. The specificity of the designed primers was checked using BLAST, which is available at the GenBank website [47]. The primer sequences for the five genes and expected PCR product sizes are shown in Table 2. A primer pair based on hem $\mathrm{M}$ gene was designed (759 bp) and was used as an internal control (Table 2).

\section{Pentaplex PCR assay}

DNA-contamination is a major problem encountered in the routine use of the PCR; we followed all contamination prevention measures in the PCR daily work to avoid pre and post-PCR contamination [48].

The monoplex PCR for each gene and the pentaplex PCR assay were standardized using genomic DNA extracted from reference Staphylococcus spp. A mixture of DNAs from two reference strains, namely $S$. aureus (ATCC 33591) and S. aureus (ATCC 25923), which contained the four genes of interest was used as a positive control. DNase-free distilled water was used as a negative control. In addition, a plasmid $\mathrm{pCR}^{\circledR} 2.1$-TOPO (Invitrogen) that contained hem $\mathrm{M}$ gene ( $1 \mathrm{pg}$ ) was used as a template for the internal control. To rule out false-negative results, an internal control (primer pair and template) was incorporated in every reaction mixture including negative controls.

Diagnostic evaluation of the pentaplex PCR was done using the lysates from 230 clinical isolates. The isolated colonies from blood agar were inoculated into LB broth and incubated at $37^{\circ} \mathrm{C}$ for $24 \mathrm{~h}$. Bacterial lysates for PCR were prepared by centrifuging the $100 \mu \mathrm{l}$ culture at 10,000 $\times g$ for $3 \mathrm{~min}$; the supernatant was removed and the pellets were resuspended in $100 \mu \mathrm{l}$ DNase-free distilled water. The suspensions were boiled in a water bath for $10 \mathrm{~min}$ and centrifuged again at 10,000 $\times g$ for $3 \mathrm{~min}$. Then, $2 \mu \mathrm{l}$ of the supernatants (lysates) was used in the pentaplex PCR assays.

The optimized concentration of primer for each gene (0.6 pmol 16 S rRNA, 0.8 pmol femA S. aureus, 1.0 pmol mecA, $0.6 \mathrm{pmol} l u k S$, and $0.8 \mathrm{pmol}$ hem $\mathrm{M}$ ) was used in the pentaplex PCR. The other components used in the PCR were $200 \mu \mathrm{M}$ dNTPs, $3.13 \mathrm{mM} \mathrm{MgCl}_{2}, 1 \times$ PCR buffer and $0.75^{2}$ U Taq DNA polymerase (Fermentas, Vilnius, Lithuania). The PCR was carried out using a Mastercycler Gradient (Eppendorf, Hamburg, Germany) with one cycle of initial denaturation at $94^{\circ} \mathrm{C}$ for $3 \mathrm{~min}, 30$ cycles of denaturation at $94^{\circ} \mathrm{C}$ for $30 \mathrm{~s}$, annealing for $30 \mathrm{~s}$ at $60^{\circ} \mathrm{C}$, and extension at $72^{\circ} \mathrm{C}$ for $30 \mathrm{~s}$, followed by an extra cycle of annealing at $60^{\circ} \mathrm{C}$ for $30 \mathrm{~s}$, and a final extension at $72^{\circ} \mathrm{C}$ for $5 \mathrm{~min}$. The PCR products were analyzed by electrophoresis on 1.5\% low EEO agarose gels (Promega, Madison, WI, USA), with ethidium bromide at $100 \mathrm{~V}$ for $75 \mathrm{~min}$. PCR products were visualized under UV illumination and photographed using an image analyzer (Chemilmager 5500; Alpha Innotech, San Leandro, CA, USA).

\section{Evaluation of pentaplex PCR assay}

Analytical specificity was evaluated using DNA lysates prepared from pure cultures of 10 phenotypically and genotypically well-characterized Staphylococcus spp. and 10 non-staphylococcal Gram-positive and 13 Gram-negative strains obtained from different sources (Table 1). The analytical sensitivity was evaluated using various concentrations of genomic DNA starting from $1 \mu \mathrm{g}$ to $10 \mathrm{pg}$ and lysate starting from $10^{8}$ to $10^{3} \mathrm{CFU} / \mathrm{ml}$ obtained from a reference strain, $S$. aureus (ATCC 33591). The diagnostic evaluation of the pentaplex PCR was carried out using 230 clinical isolates. The results were compared with the conventional microbiological, biochemical, and antimicrobial susceptibility E-test which were considered as the gold standard [20].

Table 2: Sequences of primers used for the pentaplex PCR.

\begin{tabular}{|c|c|c|c|c|}
\hline Gene & Primer Name & 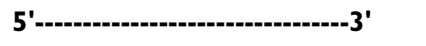 & Gen Bank accession number & Product size \\
\hline \multirow{2}{*}{$\begin{array}{l}\text { Internal } \\
\text { control hemM }\end{array}$} & IC-F & AGCAGCGTCCATTGTGAGA & AF227752 & $759 \mathrm{bp}$ \\
\hline & IC-R & ATTCTCAGATATGTGTGG & & \\
\hline \multirow[t]{2}{*}{ I6S rRNA } & I6S rRNA-F & GCAAGCGTTATCCGGATTT & D83356 & $597 \mathrm{bp}$ \\
\hline & I6S rRNA-R & CTTAATGATGGCAACTAAGC & & \\
\hline \multirow[t]{2}{*}{ femA } & femA-F & CGATCCATATTTACCATATCA & $\mathrm{CP} 000255$ & $450 \mathrm{bp}$ \\
\hline & femA-R & ATCACGCTCTTCGTTTAGTT & & \\
\hline \multirow[t]{2}{*}{ mecA } & mecA-F & ACGAGTAGATGCTCAATATAA & NC $003923 M$ & $293 \mathrm{bp}$ \\
\hline & mecA-R & CTTAGTTCTTTAGCGATTGC & & \\
\hline \multirow[t]{2}{*}{ lukS } & lukS-F & CAGGAGGTAATGGTTCATTT & $\underline{A B 186917}$ & $151 \mathrm{bp}$ \\
\hline & lukS-R & ATGTCCAGACATTTTACCTAA & & \\
\hline
\end{tabular}




\section{Statistical analysis}

The clinical sensitivity, specificity, and positive and negative predictive values of the pentaplex PCR were calculated based on the CLSI Guidelines for Molecular Diagnostic Methods for Infectious Diseases [20].

\section{Authors' contributions}

HALT carried out the DNA sequence alignment, designed the primers, developed the multiplex PCR, analyzed clinical samples and drafted the manuscript. CYY contributed to the multiplex PCR optimization. AALK contributed to the primer design and data analysis. HH was involved in the initial study design in protocol development and selection of genes. KKBS contributed to the manuscript revision. KALJ participated in the study design and critically edited and revised the manuscript. MR conceived and coordinated the study, helped in DNA sequence analysis, primer design and data analysis, and drafted the manuscript. All authors read and approved the final manuscript.

\section{Acknowledgements}

This study was supported by Short-term grant (304/PPSP/6 131535) from Universiti Sains Malaysia. We are grateful to Institute for postgraduate studies, Universiti Sains Malaysia for their Fellowship support, and Department of Medical Microbiology and Parasitology, Hospital Universiti Sains Malaysia, Kelantan, Malaysia; for providing the clinical isolates.

\section{References}

I. Diekema DJ, Pfaller MA, Schmitz FJ, Smayevsky J, Bell J, Jones RN, Beach M: Survey of infections due to Staphylococcus species: frequency of occurrence and antimicrobial susceptibility of isolates collected in the United States, Canada, Latin America, Europe, and the Western Pacific region for the SENTRY Antimicrobial Surveillance Program, 1997-1999. Clin Infect Dis 200I, 32(Suppl 2):SI I4-I32.

2. Tiemersma EW, Bronzwaer SL, Lyytikainen O, Degener JE, Schrijnemakers P, Bruinsma N, Monen J, Witte W, Grundman H: Methicillin-resistant Staphylococcus aureus in Europe, 1999-2002. Emerg Infect Dis 2004, I0(9):1627-1634.

3. Kluytmans-Vandenbergh MF, Kluytmans JA: Community-acquired methicillin-resistant Staphylococcus aureus: current perspectives. Clin Microbiol Infect 2006, I 2(SuppI I):9-I5.

4. Vandenesch F, Naimi T, Enright MC, Lina G, Nimmo GR, Heffernan $\mathrm{H}$, Liassine N, Bes M, Greenland T, Reverdy ME, et al.: Communityacquired methicillin-resistant Staphylococcus aureus carrying Panton-Valentine leukocidin genes: worldwide emergence. Emerg Infect Dis 2003, 9(8):978-984.

5. von Eiff C, Proctor RA, Peters G: Coagulase-negative staphylococci. Pathogens have major role in nosocomial infections. Postgrad Med 200I, I I 0(4):63-64.

6. von Eiff C, Peters G, Heilmann C: Pathogenesis of infections due to coagulase-negative staphylococci. Lancet Infect Dis 2002, 2(II):677-685.

7. Patrick CC: Coagulase-negative staphylococci: pathogens with increasing clinical significance. J Pediatr 1990, I I 6(4):497-507.

8. Zhang K, Sparling J, Chow BL, Elsayed S, Hussain Z, Church DL, Gregson DB, Louie T, Conly JM: New quadriplex PCR assay for detection of methicillin and mupirocin resistance and simultaneous discrimination of Staphylococcus aureus from coagulase-negative staphylococci. J Clin Microbiol 2004, 42(I I):4947-4955.

9. Perez-Roth E, Claverie-Martin F, Villar J, Mendez-Alvarez S: Multiplex PCR for simultaneous identification of Staphylococcus aureus and detection of methicillin and mupirocin resistance. J Clin Microbiol 200 I, 39(I I):4037-404I.
10. Swenson JM, Tenover FC: Results of disk diffusion testing with cefoxitin correlate with presence of mecA in Staphylococcus spp. J Clin Microbiol 2005, 43(8):3818-3823.

II. Chambers HF: Methicillin resistance in staphylococci: molecular and biochemical basis and clinical implications. Clin Microbiol Rev 1997, I0(4):78|-79|.

12. Giammarinaro P, Leroy S, Chacornac JP, Delmas J, Talon R: Development of a new oligonucleotide array to identify staphylococcal strains at species level. J Clin Microbiol 2005, 43(8):3673-3680

13. Murakami K, Minamide W, Wada K, Nakamura E, Teraoka H, Watanabe S: Identification of methicillin-resistant strains of staphylococci by polymerase chain reaction. J Clin Microbiol 1991, 29(10):2240-2244.

14. McClure JA, Conly JM, Lau V, Elsayed S, Louie T, Hutchins W, Zhang K: Novel multiplex PCR assay for detection of the staphylococcal virulence marker Panton-Valentine leukocidin genes and simultaneous discrimination of methicillin-susceptible from -resistant staphylococci. J Clin Microbiol 2006, 44(3): I|4|-|| $\mid 44$.

15. Oliveira DC, de Lencastre H: Multiplex PCR strategy for rapid identification of structural types and variants of the mec element in methicillin-resistant Staphylococcus aureus. Antimicrob Agents Chemother 2002, 46(7):2155-2161.

16. Daeschlein G, Assadian O, Daxboeck F, Kramer A: Multiplex PCRELISA for direct detection of MRSA in nasal swabs advantageous for rapid identification of non-MRSA carriers. Eur J Clin Microbiol Infect Dis 2006, 25(5):328-330.

17. Zhang K, McClure JA, Elsayed S, Louie T, Conly JM: Novel multiplex PCR assay for simultaneous identification of community-associated methicillin-resistant Staphylococcus aureus strains USA300 and USA400 and detection of mecA and Panton-Valentine leukocidin genes, with discrimination of Staphylococcus aureus from coagulase-negative staphylococci. J Clin Microbiol 2008, 46(3): I I I8- I I 22.

18. Mehrotra M, Wang G, Johnson WM: Multiplex PCR for detection of genes for Staphylococcus aureus enterotoxins, exfoliative toxins, toxic shock syndrome toxin I, and methicillin resistance. I Clin Microbiol 2000, 38(3): 1032-1035.

19. Zhang K, McClure JA, Elsayed S, Louie T, Conly JM: Novel multiplex PCR assay for characterization and concomitant subtyping of staphylococcal cassette chromosome mec types I to $\mathbf{V}$ in methicillin-resistant Staphylococcus aureus. J Clin Microbiol 2005, 43(10):5026-5033.

20. Molecular Diagnostic Methods for Infectious Diseases. Approved Guideline (CLSI MM3-A2) 2nd edition. 2006, 26:73.

21. Nolte FS-JCA, Cockerill FR, Dailey PJ, Hillyard D, McDonough S, Meyer RF, Shively RG: Molecular Diagnostic Methods for Infectious Diseases; Approved Guideline. 2006, 26:73.

22. Maes N, Magdalena J, Rottiers S, De Gheldre Y, Struelens MJ: Evaluation of a triplex PCR assay to discriminate Staphylococcus aureus from coagulase-negative Staphylococci and determine methicillin resistance from blood cultures. J Clin Microbiol 2002, 40(4): $1514-1517$.

23. Jaffe RI, Lane JD, Albury SV, Niemeyer DM: Rapid extraction from and direct identification in clinical samples of methicillinresistant staphylococci using the PCR. J Clin Microbiol 2000, 38(9):3407-34I2.

24. Vannuffel P, Gigi J, Ezzedine H, Vandercam B, Delmee M, Wauters G, Gala JL: Specific detection of methicillin-resistant Staphylococcus species by multiplex PCR. J Clin Microbiol 1995, 33(I I):2864-2867.

25. Francois P, Pittet D, Bento M, Pepey B, Vaudaux P, Lew D, Schrenzel J: Rapid detection of methicillin-resistant Staphylococcus aureus directly from sterile or nonsterile clinical samples by a new molecular assay. J Clin Microbiol 2003, 4 I (I):254-260.

26. Unal S, Hoskins J, Flokowitsch JE, Wu CY, Preston DA, Skatrud PL: Detection of methicillin-resistant staphylococci by using the polymerase chain reaction. I Clin Microbiol 1992, 30(7): |685-169|.

27. Ryffel C, Tesch W, Birch-Machin I, Reynolds PE, Barberis-Maino L, Kayser FH, Berger-Bachi B: Sequence comparison of mecA genes isolated from methicillin-resistant Staphylococcus aureus and Staphylococcus epidermidis. Gene 1990, 94(I): $137-138$. 
28. Sundsfjord A, Simonsen GS, Haldorsen BC, Haaheim H, Hjelmevoll SO, Littauer P, Dahl KH: Genetic methods for detection of antimicrobial resistance. Apmis 2004, I I 2( I I- I 2):8 I 5-837.

29. Mohanasoundaram KM, Lalitha MK: Comparison of phenotypic versus genotypic methods in the detection of methicillin resistance in Staphylococcus aureus. Indian J Med Res 2008 I 27(I):78-84.

30. Tenover FC, Jones RN, Swenson JM, Zimmer B, McAllister S, Jorgensen $\mathrm{JH}$ : Methods for improved detection of oxacillin resistance in coagulase-negative staphylococci: results of a multicenter study. J Clin Microbiol I999, 37( I 2):405 I-4058.

31. Community Associated Methicillin Resistant Staphylococcus aureus (CA MRSA). Guidelines for Clinical Management and Control of Transmission 2005. PPH 42160

32. Hsu LY, Koh TH, Kurup A, Low J, Chlebicki MP, Tan BH: High incidence of Panton-Valentine leukocidin-producing Staphylococcus aureus in a tertiary care public hospital in Singapore. Clin Infect Dis 2005, 40(3):486-489.

33. Severin JA, Lestari ES, Kuntaman K, Melles DC, Pastink M, Peeters JK, Snijders SV, Hadi U, Duerink DO, van Belkum A, et al.: Unusually high prevalence of panton-valentine leukocidin genes among methicillin-sensitive Staphylococcus aureus strains carried in the Indonesian population. J Clin Microbiol 2008, 46(6): 1989-1995.

34. Miller LG, Perdreau-Remington F, Rieg G, Mehdi S, Perlroth J, Bayer AS, Tang AW, Phung TO, Spellberg B: Necrotizing fasciitis caused by community-associated methicillin-resistant Staphylococcus aureus in Los Angeles. N Engl J Med 2005, 352(I 4): | 445-|453.

35. Francis JS, Doherty MC, Lopatin U, Johnston CP, Sinha G, Ross T, Cai $M$, Hansel NN, Perl T, Ticehurst JR, et al: Severe communityonset pneumonia in healthy adults caused by methicillinresistant Staphylococcus aureus carrying the Panton-Valentine leukocidin genes. Clin Infect Dis 2005, 40(I): I00-I07.

36. Gonzalez BE, Martinez-Aguilar G, Hulten KG, Hammerman WA, Coss-Bu J, Avalos-Mishaan A, Mason EO Jr, Kaplan SL: Severe Staphylococcal sepsis in adolescents in the era of communityacquired methicillin-resistant Staphylococcus aureus. Pediatrics 2005, I I 5(3):642-648.

37. Sabet NS, Subramaniam G, Navaratnam P, Sekaran SD: Detection of mecA and ermA genes and simultaneous identification of Staphylococcus aureus using triplex real-time PCR from Malaysian S. aureus strain collections. Int J Antimicrob Agents 2007, 29(5):582-585.

38. Alfizah $\mathrm{H}$, Norazah A, Nordiah AJ, Lim VK: DNA fingerprinting of methicillin-resistant Staphylococcus aureus (MRSA) by pulsed-field gel electrophoresis (PFGE) in a teaching hospital in Malaysia. Med J Malaysia 2002, 57(3):319-328.

39. Gosbell IB, Neville SA, Mercer JL, Fernandes LA, Fernandes CJ: Evaluation of the MRSA-Screen Test in detecting oxacillin resistance in community and hospital isolates of Staphylococcus aureus. Pathology 200I, 33(4):493-495.

40. Udo EE, Mokadas EM, Al-Haddad A, Mathew B, Jacob LE, Sanyal SC: Rapid detection of methicillin resistance in staphylococc using a slide latex agglutination kit. Int J Antimicrob Agents 2000, I 5(I): I9-24.

4I. Oliveira AD, d'Azevedo PA, de Sousa LB, Viana-Niero C, Francisco W, Lottenberg C, Martino MD, Hofling-Lima AL: Laboratory detection methods for methicillin resistance in coagulase negative Staphylococcus isolated from ophthalmic infections. Arq Bras Oftalmol 2007, 70(4):667-675.

42. Schmitz FJ, Mackenzie CR, Hofmann B, Verhoef J, Finken-Eigen M, Heinz HP, Kohrer K: Specific information concerning taxonomy, pathogenicity and methicillin resistance of staphylococci obtained by a multiplex PCR. J Med Microbiol 1997, 46(9):773-778.

43. Murray PR, (ed), et al.: Manual of clinical microbiology. 8th edition. Washington, D.C.: ASM Press; 2003.

44. National Committee for Clinical Laboratory Standards. Performance standards for antimicrobial susceptibility testing, Wayne, PA 200I, MI00-SI I:

45. GenBank [http://www.ncbi.nlm.nih.gov/Genbank/.]

46. GeneDoc [http://www.nrbsc.org/downloads/.]

47. GenBank BLAST search [http://www.ncbi.nlm.nih.gov/BLAST/.]

48. Setting up a PCR laboratory [http://www.biosupplynet.com/pdf/ OI PCR Primer p.5 14.pdf]
Publish with Bio Med Central and every scientist can read your work free of charge

"BioMed Central will be the most significant development for disseminating the results of biomedical research in our lifetime. "

Sir Paul Nurse, Cancer Research UK

Your research papers will be:

- available free of charge to the entire biomedical community

- peer reviewed and published immediately upon acceptance

- cited in PubMed and archived on PubMed Central

- yours - you keep the copyright
BioMedcentral 